\title{
Patterns of space use in sympatric marine colonial predators reveal scales of spatial partitioning
}

\author{
Esther L. Jones ${ }^{1,2, *}$, Bernie J. McConnell ${ }^{1}$, Sophie Smout ${ }^{1,2}$, Philip S. Hammond ${ }^{1,2}$, \\ Callan D. Duck ${ }^{1}$, Christopher D. Morris ${ }^{1}$, David Thompson ${ }^{1}$, Deborah J. F. Russell ${ }^{1,2}$, \\ Cecile Vincent $^{3}$, Michelle Cronin ${ }^{4}$, Ruth J. Sharples ${ }^{5}$, Jason Matthiopoulos ${ }^{6}$
}

\footnotetext{
${ }^{1}$ Sea Mammal Research Unit, Scottish Oceans Institute, University of St Andrews, St Andrews KY16 8LB, UK

${ }^{2}$ Centre for Research into Ecological and Environmental Modelling, The Observatory, Buchanan Gardens, University of St Andrews, St Andrews KY16 9LZ, UK
}

${ }^{3}$ CEBC, UMR 7372 CNRS/University of La Rochelle, Institut du Littoral et de l'Environnement (ILE), 2 rue Olympe de Gouges, 17000 La Rochelle, France

${ }^{4}$ Coastal \& Marine Research Centre, University College Cork, Naval Base, Haulbowline, Co. Cork, UK

${ }^{5}$ Institute of Marine and Antarctic Studies, University of Tasmania, IMAS Sandy Bay, Private Bag 129, Hobart, TAS 7001, Australia

${ }^{6}$ University of Glasgow, Institute of Biodiversity, Animal Health and Comparative Medicine, Graham Kerr Building, Glasgow G12 8QQ, UK

\begin{abstract}
Species distribution maps can provide important information to focus conservation efforts and enable spatial management of human activities. Two sympatric marine predators, grey seals Halichoerus grypus and harbour seals Phoca vitulina, have overlapping ranges on land and at sea but contrasting population dynamics around Britain: whilst grey seals have generally increased, harbour seals have shown significant regional declines. We analysed 2 decades of atsea movement data and terrestrial count data from these species to produce high resolution, broad-scale maps of distribution and associated uncertainty to inform conservation and management. Our results showed that grey seals use offshore areas connected to their haul-out sites by prominent corridors, and harbour seals primarily stay within $50 \mathrm{~km}$ of the coastline. Both species show fine-scale offshore spatial segregation off the east coast of Britain and broad-scale partitioning off western Scotland. These results illustrate that, for broad-scale marine spatial planning, the conservation needs of harbour seals (primarily inshore, the exception being selected offshore usage areas) are different from those of grey seals (up to $100 \mathrm{~km}$ offshore and corridors connecting these areas to haul-out sites). More generally, our results illustrate the importance of detailed knowledge of marine predator distributions to inform marine spatial planning; for instance, spatial prioritisation is not necessarily the most effective spatial planning strategy even when conserving species with similar taxonomy.
\end{abstract}

KEY WORDS: Halichoerus grypus · Phoca vitulina · Density estimation · Propagating uncertainty Species distribution $\cdot$ Telemetry $\cdot$ Area-based conservation

\section{INTRODUCTION}

Anthropogenic activities directly (e.g. fisheries, energy extraction, shipping traffic; Merchant et al. 2014) and indirectly (e.g. prey depletion due to fisheries, climate change; Guénette et al. 2006) impact on the marine environment to an increasing spatial extent and intensity. Apex predators are particularly vulnerable to such impacts because their K-selected life histories limit the speed at which they can respond to reductions in population size. Anthropogenic activities at sea can affect marine predator dis- 
tributions, particularly in the context of area-based conservation of species and in relation to the management of these activities, such as the rapid development of renewable energy extraction. One focus of area-based conservation in the marine environment is the identification of areas with a high abundance of apex predators (Hooker et al. 2011). However, areas shared by multiple predator species may not include optimal habitat for any of those species (Williams et al. 2014). Williams et al. (2014) found that, at a regional scale, areas of greatest overlap in marine mammal distributions excluded areas of highest density for all species. Marine mammals are commonly used as indicators of ecosystem health (Boyd et al. 2006, Piatt \& Sydeman 2007), and a good understanding of how their abundances are distributed is essential if marine protected areas (MPAs) for them are to be effective.

There are a number of habitat-based methods for mapping species distributions (Matthiopoulos \& Aarts 2010). However, these methods are based on model predictions and require covariate data, which may limit the geographical area over which predictions can be made. When the focus is purely on spatial patterns, density estimation methodology offers a flexible alternative in which the spatial extent is not restricted by external covariates (Silverman 1986). Density estimation is data-driven and does not rely on model predictions, making it particularly suitable for estimating species distributions where movement and population data are available and can be linked explicitly. Combining density-estimation methods with simple habitat models using (distancebased) covariates that are universally available to predict in areas where movement data are absent, we develop a generalised framework to produce species distribution maps for terrestrial and marine animals integrating animal movement and population data. Obtaining robust population-level insights from individual animal data is challenging because such data can be difficult and expensive to collect and because the sample must be proportional to the animals' prevalence in the population. Many factors affect the precision of inference from limited sampling, such as the underlying population structure and consistency in spatio-temporal behaviour. We propagate uncertainty through the entire analysis from movement and population data to estimated space use distributions.

Our study focusses on grey and harbour seals, 2 sympatric species that inhabit much of the coasts and continental shelf waters of northwest Europe. They are listed under Annex II of the European Habitats
Directive, which requires designation of MPAs; these exist for terrestrial sites, but marine sites have not yet been proposed (JNCC 2010). As central place foragers, grey and harbour seal access to the marine environment is restricted by the need to return to shore periodically between foraging trips (Matthiopoulos et al. 2004). The 2 species have overlapping ranges on land and at sea, similar but variable diets, and comparable but asynchronous life-cycles (McConnell et al. 1999, Sharples et al. 2009, Brown et al. 2012). They may therefore be expected to display spatial niche partitioning to some extent. If the spatial component of niche partitioning at sea is strong, with little overlap in areas of highest density, this would have implications for designation of marine MPAs based on relative abundance. Designating MPAs for multiple species, sometimes known as 'double badging', is one way for management authorities to strengthen conservation measures within limited resources. However, this would not be effective if there were strong evidence of spatial partitioning.

An issue of particular interest is that although grey and harbour seals are sympatric species and are therefore likely to be facing the same environmental stressors, they show opposing population trends in some areas around Britain, which comprises the majority of our study area. Grey seal numbers have generally increased since at least 1984 and, although stable in the Western and Northern Isles, are still increasing in the North Sea (Thomas 2013). Harbour seals have declined in Orkney, Shetland and the east coast of Scotland since around 2000 but are stable in the Western Isles (Lonergan et al. 2007, Duck et al. 2013). Possible causes of declines in harbour seal numbers include direct mortality from vessel interactions (Bexton et al. 2012), the effects of infectious diseases (Hall et al. 2006, Harris et al. 2008), biotoxin exposure (Hall \& Frame 2010) and interspecific competition with grey seals (Bowen et al. 2003, Svensson 2012). Knowledge of regional variation in the extent of overlap in the at-sea distributions of grey and harbour seal populations could help to inform whether the 2 species compete for food.

Here, we synthesise $>2$ decades of population and movement data around the continental shelf of Britain, Ireland and France for 2 sympatric seal species. We describe species distributions for grey and harbour seals, defined as 'usage', with robust estimates of uncertainty and investigate patterns of spatial partitioning between the species. Our results are thus important to inform the placement of areas for conservation, including in the context of concern 


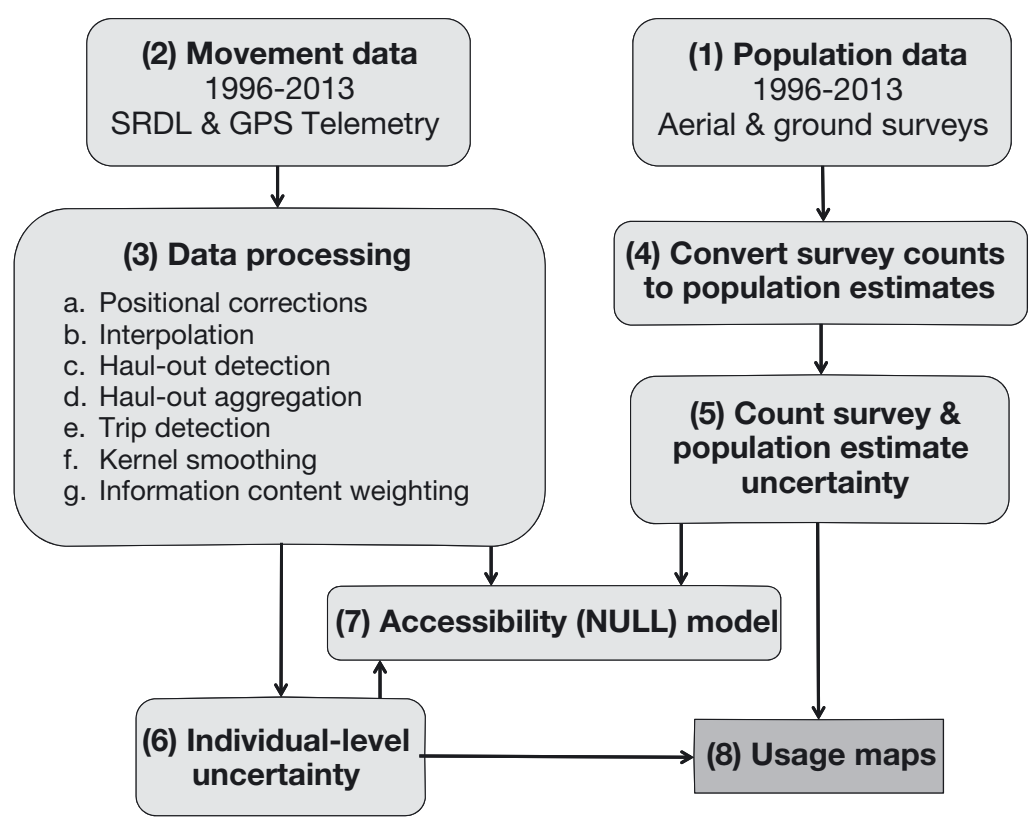

Fig. 1. Flowchart representing high-level analytical methodology

Table 1. Fig. 2 shows the locations of terrestrial counts.

(2) Movement data. Telemetry data from grey and harbour seals were obtained from 2 types of logging device: satellite relay data logger (SRDL) tags that use the Argos satellite system for data transmission and GPS phone tags that use the GSM mobile phone network with a hybrid Fastloc protocol (McConnell et al. 2004, Argos 2011). Telemetry data were processed through a set of data-cleansing protocols to remove null and missing values and duplicated records from the analysis. Details of telemetry data are available in Supplement 1 at www. int-res.com/articles/suppl/m534p235_ supp.pdf.

(3a) Positional corrections. Positional error, varying from $50 \mathrm{~m}$ to $>2.5 \mathrm{~km}$, affects SRDL telemetry points. Errors

about harbour seal population declines. They are also important to inform other aspects of marine spatial planning, including local developments such as wind farms and tidal turbines. The methods developed here can readily be used in other situations where the ranges of central-place foragers (e.g. other pinnipeds, breeding seabirds and terrestrial predators) overlap and may be useful for informing marine spatial planning issues in these cases.

\section{METHODS}

Fig. 1 shows a schematic flowchart of the analytical process, which synthesises movement and population data to produce usage maps with accompanying uncertainty. Analyses were conducted using R 3.0.2 (R Core Team 2014), and maps were produced using Manifold 8.0.28.0 (Manifold Software 2013).

(1) Population data. Grey and harbour seals are surveyed by the Sea Mammal Research Unit (SMRU) during August when harbour seals are moulting and haul-out on land for an extended period. During standard aerial surveys, all seals along a specified coastline are counted and coordinates are recorded to an accuracy of up to $50 \mathrm{~m}$. Surveys take place within $2 \mathrm{~h}$ of low tide when low tide is between 12:00 and 18:00 h (Thompson et al. 2005, Lonergan et al. 2011). Ground- and boat-based count data collected by other organisations were also used in the analysis, and all sources of data collection are summarised in were assigned by the Argos system to 6 location quality classes. We developed a Kalman filter to obtain position estimates accounting for observation error (Royer \& Lutcavage 2008). SRDL data were first speed-filtered at $2 \mathrm{~m} \mathrm{~s}^{-1}$ to eliminate outlying locations that would require an unrealistic travel speed (McConnell et al. 1992). Observation model parameters were provided by the location quality class errors from Vincent et al. (2002), and process model parameters were derived by species from the average speeds of all GPS tags. GPS tags are generally more accurate than SRDL tags, and $75 \%$ of these data have an expected error of $\leq 55 \mathrm{~m}$ (Dujon et al. 2014). However, occasional outliers were excluded using thresholds of residual error and number of satellites.

(3b) Interpolation. Movement SRDL data were interpolated to $2 \mathrm{~h}$ intervals using output from the Kalman filter and merged with linearly interpolated GPS data that had been regularised to $2 \mathrm{~h}$ intervals. A regular grid of $5 \mathrm{~km}$ resolution was created to encompass all telemetry data; $5 \mathrm{~km}$ was selected based on the computational trade-off between the resolution and spatial extent of the final maps. Data from 259 grey seal tags (Fig. 3a; see Table S1 in Supplement 1) and 277 harbour seal tags were used (Fig. 3b; see Table S2 in Supplement 1). The patterns of movement of the tagged animals were assumed to be representative of the whole population (Lonergan et al. 2011). Tag deployment occurs outside each species breeding and moulting seasons, and tags usually fall off when animals moult. Therefore, although telemetry data 
Table 1. Summary of grey and harbour seal terrestrial surveys. Unless specified otherwise in the description, all surveys took place during August. SMRU: Sea Mammal Research Unit

\begin{tabular}{|c|c|c|c|}
\hline Area surveyed & Method & Description & Data used \\
\hline Scotland & Aerial survey (helicopter) & $\begin{array}{l}\text { Both species surveyed every } \\
1 \text { to } 5 \text { yr using SMRU protocol }\end{array}$ & 1996-2013 \\
\hline $\begin{array}{l}\text { Moray Firth, Firth of Tay, Donna } \\
\text { Nook, The Wash in East Anglia, } \\
\text { and Thames estuary }\end{array}$ & Aerial survey (fixed-wing) & $\begin{array}{l}\text { Both species surveyed annually } \\
\text { using SMRU protocol }\end{array}$ & $1996-2013$ \\
\hline Chichester and Langstone harbour & $\begin{array}{l}\text { Ground counts through Chichester } \\
\text { Harbour Authority }\end{array}$ & $\begin{array}{l}\text { Harbour seals surveyed } \\
\text { annually }\end{array}$ & 1999-2012 \\
\hline $\begin{array}{l}\text { Cornwall and Isles of Scilly, } \\
\text { south-west England }\end{array}$ & Boat survey (Leeney et al. 2010) & Grey seals surveyed in April & 2007 \\
\hline Isles of Scilly & Ground counts (Sayer et al. 2012) & Grey seals & 2010 \\
\hline North Wales & Ground counts (Westcott \& Stringell 2004) & $\begin{array}{l}\text { Grey seal counts extended } \\
\text { over } 12 \text { mo }\end{array}$ & 2002,2003 \\
\hline Skomer Island, West Wales & Ground counts & Adult grey seals & 2013 \\
\hline Ramsey Island, West Wales & Ground counts & Grey seals & $2007-2011$ \\
\hline Northern Ireland & Aerial survey (helicopter) & $\begin{array}{l}\text { Both species surveyed } \\
\text { using SMRU protocol }\end{array}$ & 2002 \\
\hline Strangford Lough, Northern Ireland & Aerial survey (helicopter) & $\begin{array}{l}\text { Both species surveyed } \\
\text { using SMRU protocol }\end{array}$ & $\begin{array}{l}\text { 2006, 2007, } \\
2008 \text { and } 2010\end{array}$ \\
\hline Republic of Ireland & Aerial survey (helicopter) & $\begin{array}{l}\text { Both species surveyed } \\
\text { using SMRU protocol }\end{array}$ & 2003 \\
\hline Northern France & $\begin{array}{l}\text { Ground counts with extrapolation } \\
\text { (Hassani et al. 2010) }\end{array}$ & Harbour seals surveyed annually & 1996-2008 \\
\hline
\end{tabular}

were collected year-round, data collection occurred primarily between June and December for grey seals and between January and June for harbour seals.

(3c) Haul-out detection. Haul-out events for both SRDL and GPS tags were defined as starting when the tag sensor had been continuously dry for $10 \mathrm{~min}$ and ending when the tag had been continuously wet for $40 \mathrm{~s}$. Haul-out event data were combined with positional data using date/time matching by individual animal. Each event was then assigned to a particular geographical location. In the intervening periods between successive haul-out events, a tagged animal was assumed to be at sea (if the tag provided such information) or in an unknown state (if the tag did not). (3d) Haul-out aggregation. Haul-out sites (defined by the telemetry data as any coastal location where at least 1 haul-out event had occurred) were aggregated into $5 \times 5 \mathrm{~km}^{2}$ grids (defined above). Haul-out events occur on land or intertidal sandbanks. Haulout sites were associated with a terrestrial count in order to scale the analysis to population level. First, telemetry haul-outs were linked to terrestrial counts based on matching their grid cells. Second, if no match could be found, the nearest valid haul-out site visited by the animal either directly before or after the unmatched haul-out site event was chosen. Third, if an animal had never been to a haul-out with associated terrestrial data during the time it was tagged, count information was assigned from the nearest haul-out based on Euclidean distance.

(3e) Trip detection. Seals move between different haul-out sites. The movements of individuals at sea were divided into trips, defined as the sequence of locations between defined haul-out events. Each location in a trip was assigned to a haul-out site. After spending time at sea, an animal could either return to its original haul-out (classifying this part of the data as a return trip) or move to a new haul-out (giving rise to a transition trip). Journeys between haul-out sites were divided temporally into 2 equal parts, and the corresponding telemetry data were attributed to the departure and termination haul-outs.

(3f) Kernel smoothing. Telemetry data are locations recorded at discrete time intervals. To transform these into spatially continuous data representing the proportion of time animals spent at different locations, we kernel smoothed the data. The KS library in R (Chacón \& Duong 2010) was used to estimate spa- 


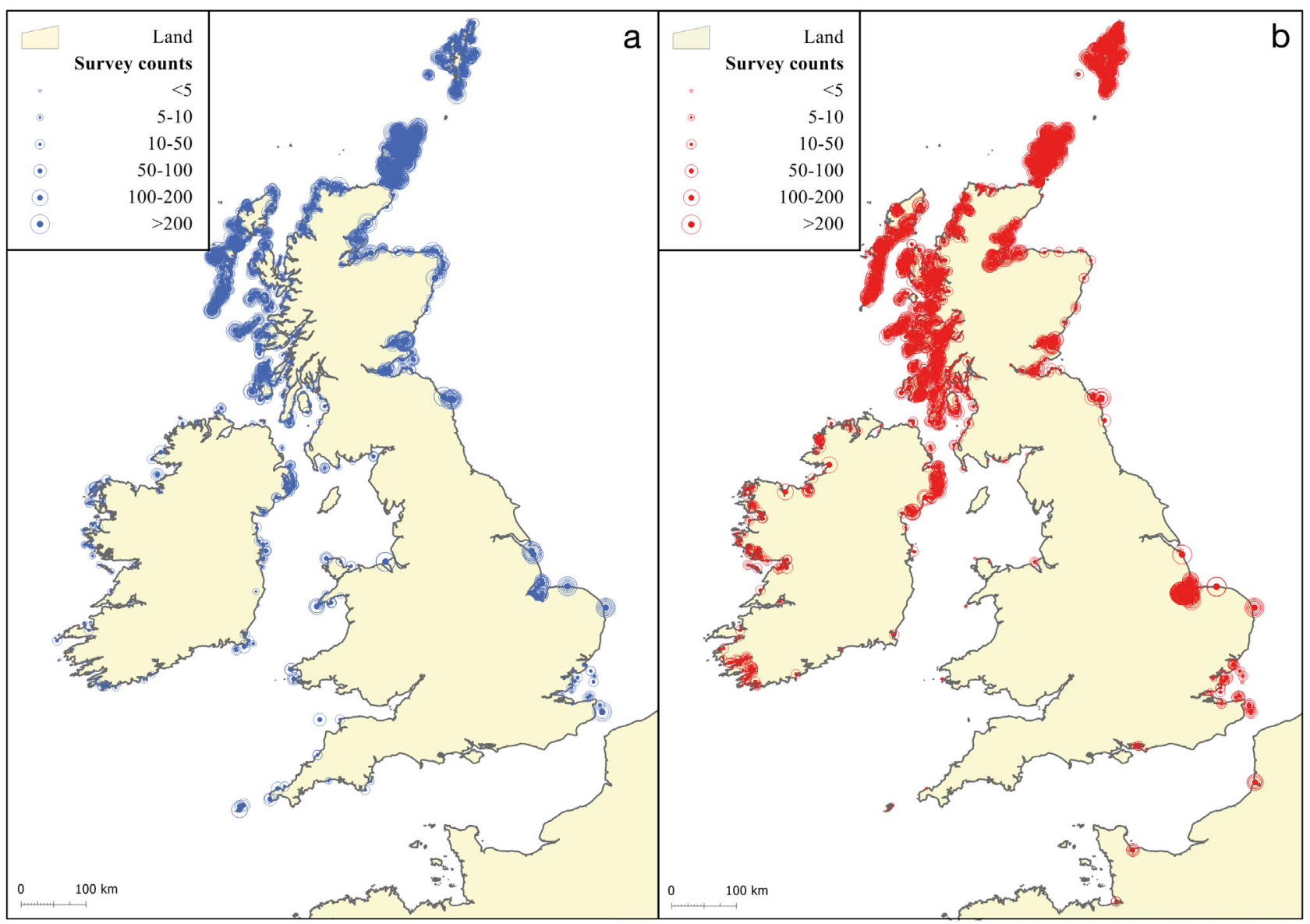

Fig. 2. (a) Grey and (b) harbour seal terrestrial counts between 1996 and 2013 for the British Isles and the European coasts of the English Channel. Global Self-consistent, Hierarchical, High-resolution Geography Database (GSHHG) shoreline data from NOAA were used in Figs. 2, 3, 4, 6 \& 7, available from www.ngdc.noaa.gov/mgg/shorelines/gshhs.html

tial bandwidth of the 2D kernel applied to each ani$\mathrm{mal} /$ haul-out map using the unconstrained plug-in selector ('Hpi') and kernel density estimator ('kde') to fit a usage surface. Kernel smoothing can be sensitive to the choice of smoothing parameter and serial correlation in the observations. However, thinning the data to eliminate autocorrelation would have meant a significant loss of information. Instead, the average tag duration (grey seals $=124 \mathrm{~d}$, harbour seals $=99 \mathrm{~d}$ ) was determined to be long enough to counteract bandwidth sensitivity (Blundell et al. 2001, Fieberg 2007). Only at-sea locations were smoothed because haul-outs were fixed locations and known without uncertainty at the scale of the analysis. Therefore, haul-out locations were incorporated back into the maps as discrete grid square usages.

(3g) Information content weighting. To account for differences in tag operation duration, an Index of
Information Content (Supplement 2 at www.int-res. com/articles/suppl/m534p235_supp.pdf) was derived. This process ensured the importance of animals with short tag-lifespans was reduced and animals with heavily auto-correlated location data were not overrepresented. A 'discovery' rate was determined for each species, defined as the total number of new grid cells visited as a function of tag lifespan, and modelled using generalised additive models (Wood 2006, 2011). Explanatory covariates were tag lifespan, type of tag (SRDL or GPS) and (for grey seals) age of each animal (1+ or pup). Each animal/haul-out map was multiplied by a normalised discovery rate (termed an 'information content weighting'), and all maps connected to each haul-out were aggregated and normalised to 1 .

(4) Population scaling. The population at each haulout was estimated from terrestrial count data, which were rescaled to allow for the proportion of animals 


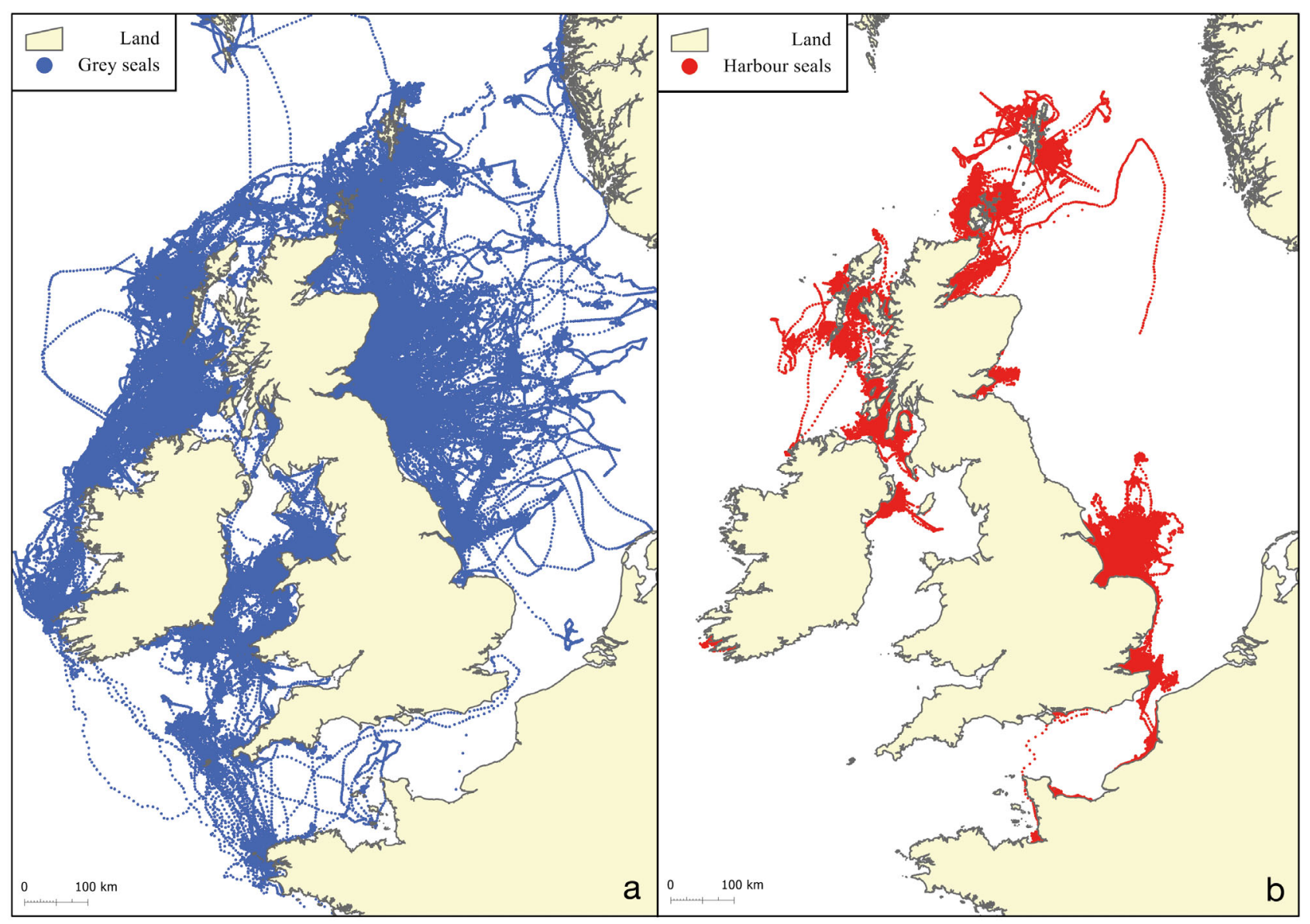

Fig. 3. (a) Grey seal telemetry tracks between 1991 and 2013 showing 259 animals; (b) harbour seal telemetry tracks between 2003 and 2013 showing 277 animals

that were at sea when surveys were carried out. Using the mean species haul-out probabilities over all available months and their variances, we derived a distribution (Supplement 3 at www.int-res.com/ articles/suppl/m534p235_supp.pdf) of population estimates ranging from the value of each terrestrial count (minimum population size) to 100 times the count (maximum population size). The distribution was sampled using parametric bootstrapping 500 times per count to produce a distribution of estimates. These data were then processed through a decision tree to produce current population estimates and variances, given the limitations in fine-scale data. Hereon, population numbers are given based on these estimates.

(5) Population uncertainty. Population-level uncertainty incorporated observational, sampling and scaling errors (Supplement 3). 'Population scaling' (explained above) produced estimates of population variance for each haul-out.
(6) Individual-level uncertainty. Within haul-out uncertainty accounted for the differences in the magnitude of data collected by an animal over its tag lifespan and for variation in the parameters of the tag itself. Variance was modelled using datarich sites (determined experimentally to be those sites which had $\geq 7$ animals associated with them) (Supplement 3). Variance was estimated using linear models with explanatory covariates of sample size (number of animals at the haul-out) and mean usage of seals. The models predicted variance for data-poor and null usage sites (where population data existed but movement data did not; see 'Accessibility modelling' below). Within-haul-out variance was estimated for null usage sites by setting the sample size of the uncertainty model to 0 . Individual and population-level variances were combined to form uncertainty estimates for the usage maps (Supplement 3). Usage and variance by haul-out were aggregated to a total usage and 
variance map for each species. Estimates of haulout usage were then added to at-sea usage to generate maps of total usage.

(7) Accessibility modelling. For haul-outs that had terrestrial counts but did not have associated telemetry data, we estimated usage in the form of accessibility maps (see Supplement 4 at www.int-res. com/articles/suppl/m534p235_supp.pdf). We modelled the expected decay of usage with increasing distance from the haul-out in the absence of between haul-out spatial heterogeneity. To ensure the spatial extent of the analysis was not restricted by availability of environmental data, simple habitat models were built using covariates of geodesic and shore distance from haul-out in a generalised linear model for each species (McCullagh \& Nelder 1989). Previous studies have shown that UK grey and harbour seal habitat preference is primarily driven by distance to haul-out site (geodesic distance) (Aarts et al. 2008, Bailey et al. 2014). The model predicted usage for each haul-out that was normalised and weighted by the mean proportion of time animals spent not hauled out. Mean and variance were scaled to population size by combining each one with the population mean and variance estimates of each haul-out, and these were aggregated to the total usage map for each species.

(8) Spatial comparisons between species. To compare spatial use between species, an index $\left(s_{i}=\right.$ $\left.M_{i(\mathrm{Hg})}-M_{i(\mathrm{Pv})}\right)$ was calculated to show the global difference in the 2 species' at-sea distributions, where estimated usage $\left(M_{i}\right)$ was the number of animals expected to use grid cell $i$. (Hg) refers to grey seals, $(\mathrm{Pv})$ refers to harbour seals.

The methodology described above is based on Matthiopoulos et al. (2004). However, the methodology was changed significantly and extended to ensure the analysis could be resolved to a fine-scale, that all available telemetry data could be included (see 'Trip detection') and that more sources of variability were incorporated and propagated through the analysis to produce continuous uncertainty estimates.

\section{RESULTS}

Using data from 259 grey seal and 277 harbour seal telemetry tags deployed between 1991 and 2013, we combined terrestrial counts collected between 1996 and 2013. Combined hauled-out and at-sea usage data of grey and harbour seals around Britain, Ireland and France are scaled to contemporary population levels (2013) and are shown in Fig. 4, with uncertainty. Both species' usage is concentrated around Scotland, reflecting the terrestrial distribution of seals around Britain, Ireland and France (Duck \& Morris 2013). Grey seal distribution is widespread with high-usage areas close to the coast linked with high usage offshore (Fig. 4a). In some areas, these offshore areas coincide with rocky ridges, such as Stanton Banks south of Barra, west Scotland, and with sandbanks, such as West Bank in the Moray Firth and Dogger Bank in the southern North Sea (see Fig. 7 for named locations). The linking corridors of usage provide insight into how grey seals move between regions. Grey seal usage extends over the continental shelf off the west coast of Scotland and Ireland. The largest aggregation of high usage was around the Orkney Islands. Grey seal usage around Ireland was primarily coastal, with limited movement between Ireland and other areas of high usage around Britain.

In contrast, Fig. 4b shows that harbour seals remain close to the coast in a number of apparently discrete local populations around Britain and Ireland, with little movement among them. However, in the Moray Firth and Firth of Tay, eastern Scotland, they spent time offshore at Smith Bank and Marr Bank, and from The Wash, England, they travelled to sandbanks up to $150 \mathrm{~km}$ offshore (see Fig. 7 for named locations). Offshore usage from The Wash in particular can be seen in fine-scale detail due to the large sample size (59 tagged animals) in this region. At-sea usage of each species calculated within buffers of increasing distance from the coast shows that harbour seals were more likely to stay close to the coast, spending only $3 \%$ of their time at distances $>50 \mathrm{~km}$ from the coast (Fig. 5). In contrast, grey seals spent $12 \%$ of their time at distances $>50 \mathrm{~km}$ from the coast. Movements of harbour seals, shown by the data underpinning the usage maps, confirm that although they do not usually travel as far offshore as grey seals, they do exhibit considerable movement parallel to the coast, resulting in concentrated patches of high coastal usage.

Fig. 6 shows the difference, by grid cell, between the predicted abundance of grey and harbour seals as a measure of the distribution of each species relative to the other. Grey seal prevalence is expected because the population is much larger than that of harbour seals. From the usage maps, estimated total abundance of grey seals is 109500 (95\% CI = 75900 to 185400), and the estimate of harbour seals is 44000 (95\% CI = 20800 to 68000$)$, which are similar 


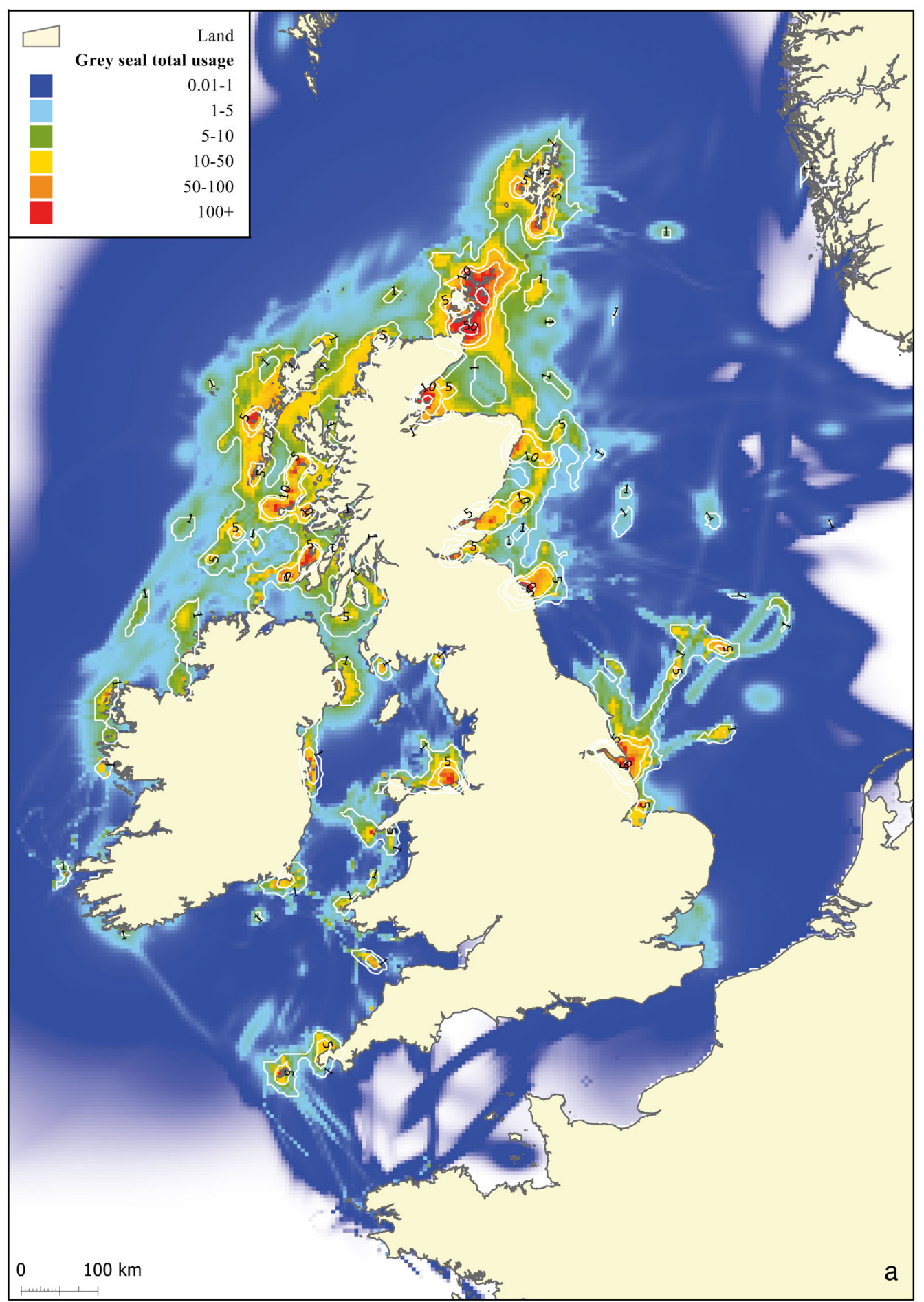

Fig. 4. The predicted number of (a) grey seals and (b) harbour seals in each $5 \times 5 \mathrm{~km}^{2}$ grid square, e.g. a yellow square denotes between 10 and 50 seals are within that grid square. White contour lines denote standard deviation from the mean as a measure of uncertainty around the estimated usage. Labels show the standard deviation value at each contour

to the published UK population estimates for 2012 for grey (Ó Cadhla et al. 2013, Thomas 2013) and harbour seals (Duck et al. 2013). Harbour seals were dominant in the southernmost part of the North Sea, around specific haul-out sites in northern France, west Scotland, parts of Ireland, and in localised offshore patches in the Moray Firth, off the west coast Orkney, and around Shetland. 


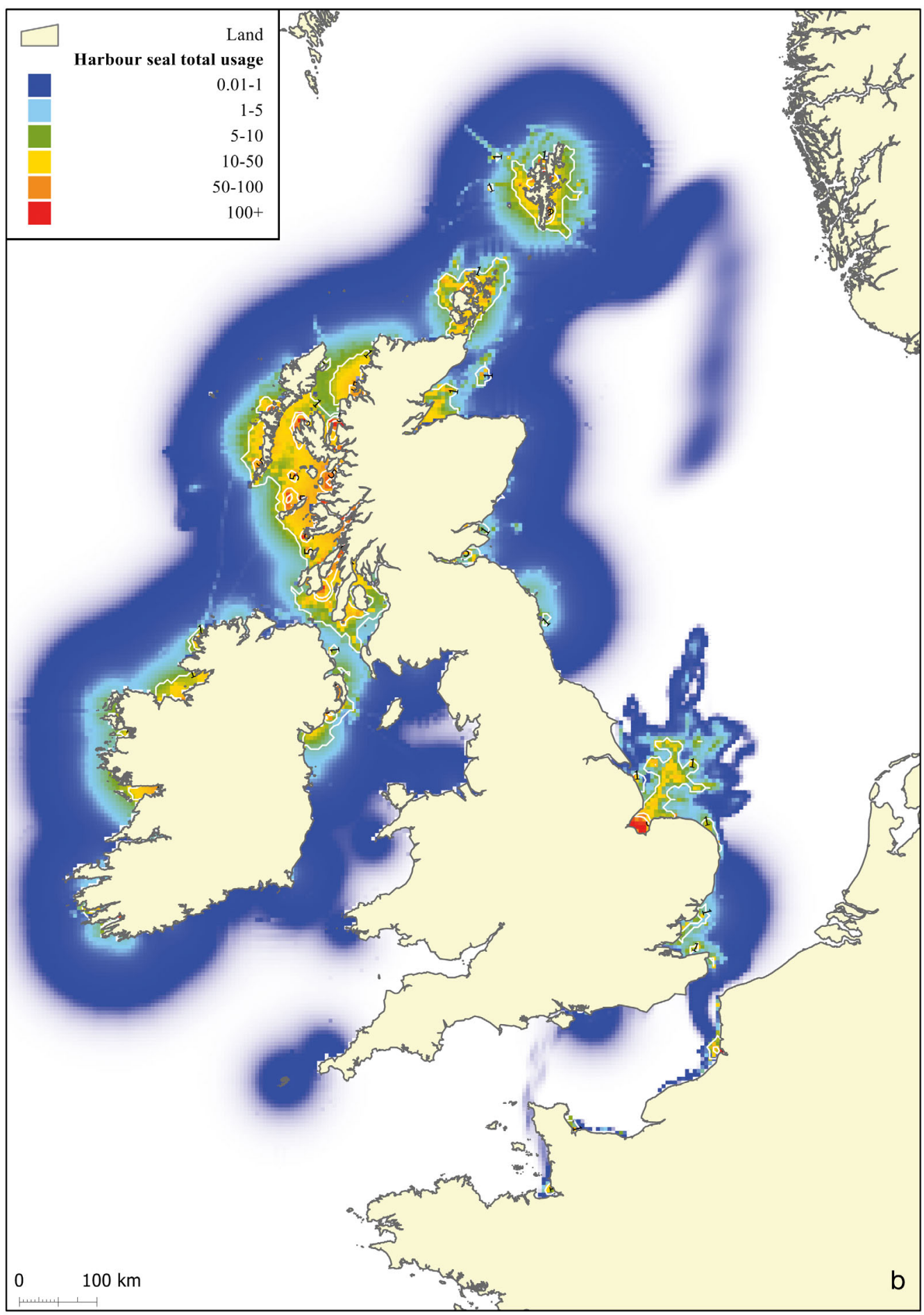

Fig. 4. Continued

\section{DISCUSSION}

We describe for the first time the species distributions of 2 sympatric marine predators in fine resolution and at a broad-scale with estimates of uncertainty. Our analysis allows us to compare patterns of marine space use between the 2 species to provide insight into the extent to which they divide or share the common space available to them. In the context of variation in regional population trajectories, we can explore how patterns of spatial overlap between the species at sea relate to recent declines in some 


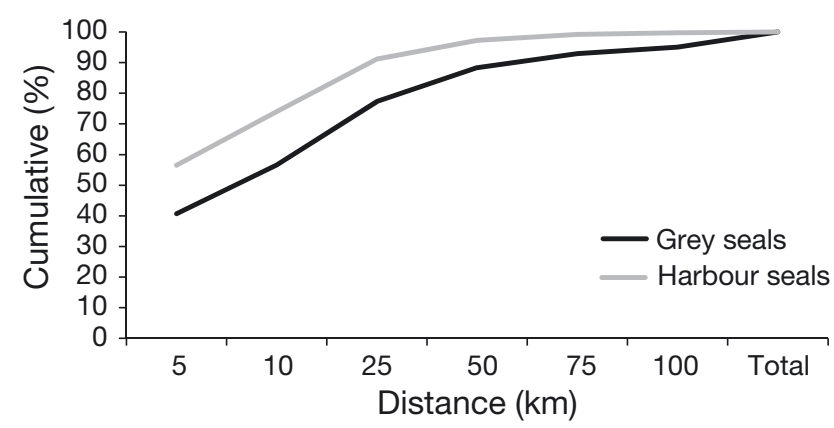

Fig. 5. Cumulative spatial usage of grey and harbour seals as a function of distance from the coast

harbour seal populations. An application of our results is that they enable us to provide scientific advice on the areas of most importance to each species to inform conservation and management. Our results show that at-sea usage of harbour seals is heterogeneous with small patches of highly concentrated numbers of animals, indicative of the discrete regional populations found around Britain, Ireland and France (Vincent et al. 2010, Cronin 2011, Sharples et al. 2012). On the east coast, harbour seals spend a high proportion of time at offshore sandbanks, indicative of foraging areas (Thompson et al. 1996). In contrast, grey seal usage is characterised by a series of interconnected highly utilised offshore areas that include known foraging sites (Matthiopoulos et al. 2004, McClintock et al. 2012). These differences in the way the 2 species use the marine environment may have consequences for their population dynamics in relation to changes in local prey availability (Sharples et al. 2009), disease transmission (Herreman et al. 2011) and their vulnerability to metapopulation collapses (Coltman et al. 1998, Matthiopoulos et al. 2005). In the southeastern North Sea, where there is a separation of usage between grey and harbour seals, harbour seal numbers are increasing. This pattern is repeated at a finer-scale in the Moray Firth, an area where the harbour seal population has historically fluctuated but has appeared to stabilise in recent years (Duck et al. 2013). In both these areas, harbour seals utilise different offshore sandbanks, which are likely foraging areas (Tollit et al. 1998, McClintock et al. 2012). However, in the Firth of Tay (see Fig. 7), where the population of harbour seals has declined to $<200$ animals (Duck et al. 2013), both species utilise the same offshore areas. West of Scotland and around Ireland, harbour seal populations are stable, and the seals use coastal areas (such as sea lochs and harbours) that grey seals do not, suggest- ing an inshore foraging distribution. These patterns give an indication that offshore spatial overlap may be detrimental to harbour seals, but further studies incorporating information on seal diet, body condition, and prey distribution and abundance are required before conclusions can be reached. However, there is corroborating evidence from other populations where the species co-exist to demonstrate that interspecific competition between grey and harbour seals is prevalent. Within their range, grey and harbour seals co-exist in the northeast Atlantic and along the east coasts of North America and Canada. A decline in harbour seals throughout the 1990s at Sable Island, Canada, has been partly attributed to inter-specific competition for shared food resources with grey seals (Bowen et al. 2003). On the east coast of the USA, in New England, seal haul-out sites that were once dominated by harbour seals are now designated as shared sites or dominated by grey seals (Gilbert et al. 2005, Waring et al. 2010). Recent abundance estimates indicate the harbour seal population may be declining, and therefore, the increasing and spatially expanding grey seal population needs to be evaluated (Gordon Waring pers. comm).

\section{Assumptions and limitations}

We assumed that the spatial distributions of each species were in equilibrium to allow $22 \mathrm{yr}$ of movement data to be integrated. Inter-annual variability in the movement data was captured in the maps so that they show the largest extent to distributions possible. However, population dynamics of both species have changed considerably in recent history, and therefore, pressures of density dependence at some haulouts may have altered, speculatively leading to changes in the metapopulation dynamics of each species. Therefore, we recommend that future telemetry deployments should carry out repeat tagging for each species in areas of recent population change, in similar areas to enable estimates of temporal heterogeneity in spatial distribution that could be integrated into haul-out uncertainty estimates. Parameters differed between telemetry tags depending on the purpose for which they were built. Two processes enabled the tags to be directly compared: regularising the tracks accounted for differences in call attempts, call abortions, haul-out sampling rates and the minimum number of satellites needed; weighting individual animals by their 'Information Content Weighting' (Supplement 2) accounted for 


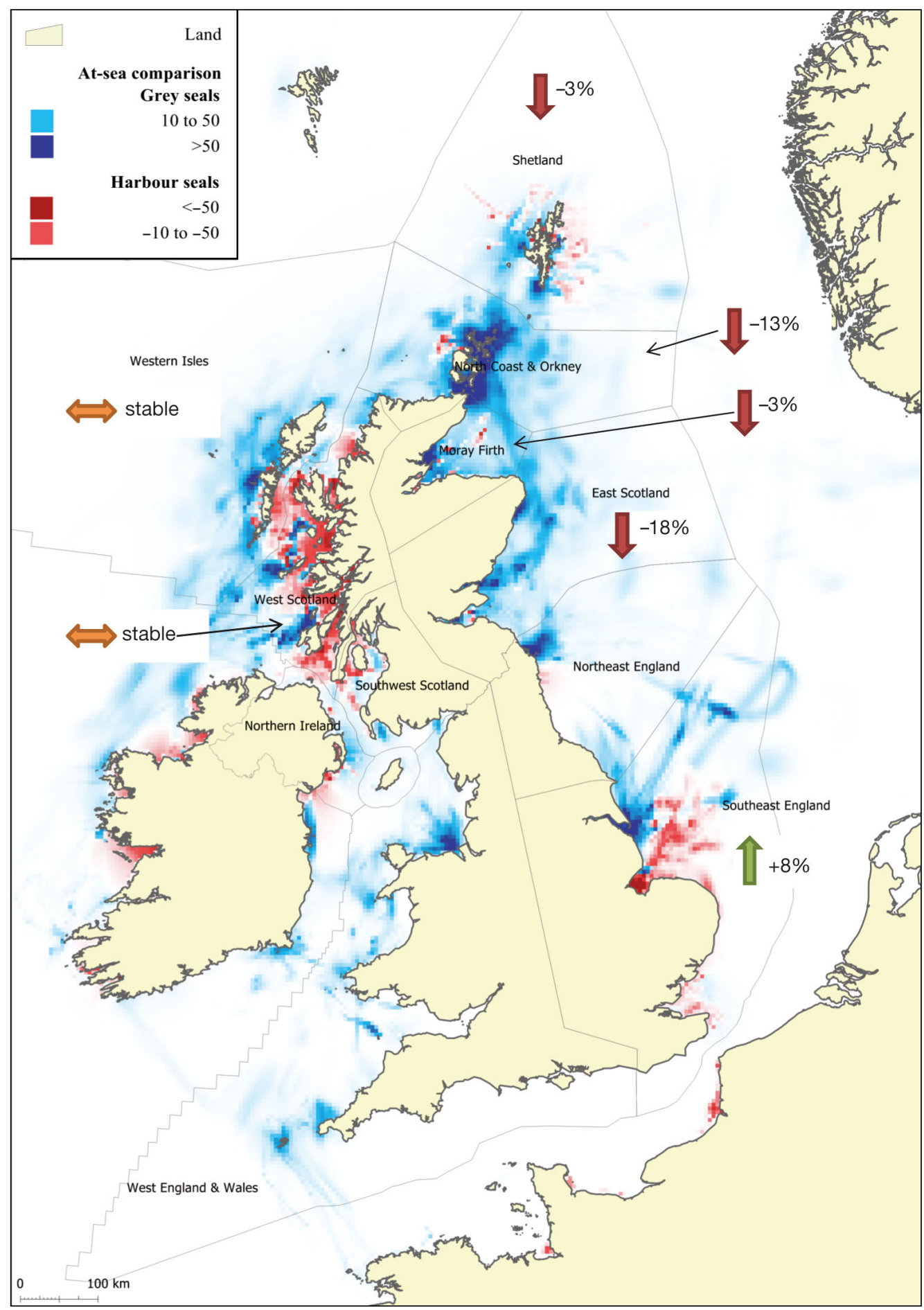

Fig. 6. Spatial at-sea comparisons between grey and harbour seals at $5 \times 5 \mathrm{~km}^{2}$ resolution showing absolute difference in population numbers. Red denotes greater harbour seal usage; blue denotes greater grey seal usage. Traffic light indicator arrows show the population trajectories (2000-2010) of harbour seals in relation to each Seal Management Unit (SMU), and the accompanying text shows the per annum change in moult counts for harbour seals (Duck et al. 2013)

the cut-off date for call attempts and the wet/dry sensor failure criteria.

The at-sea and on-land distributions of grey and harbour seals vary seasonally (Thompson et al. 1996) and annually (Duck \& Morris 2013, Duck et al. 2013). Therefore, to directly compare distributions at a population level, we used terrestrial count data of both species from August. There were seasonal gaps in 


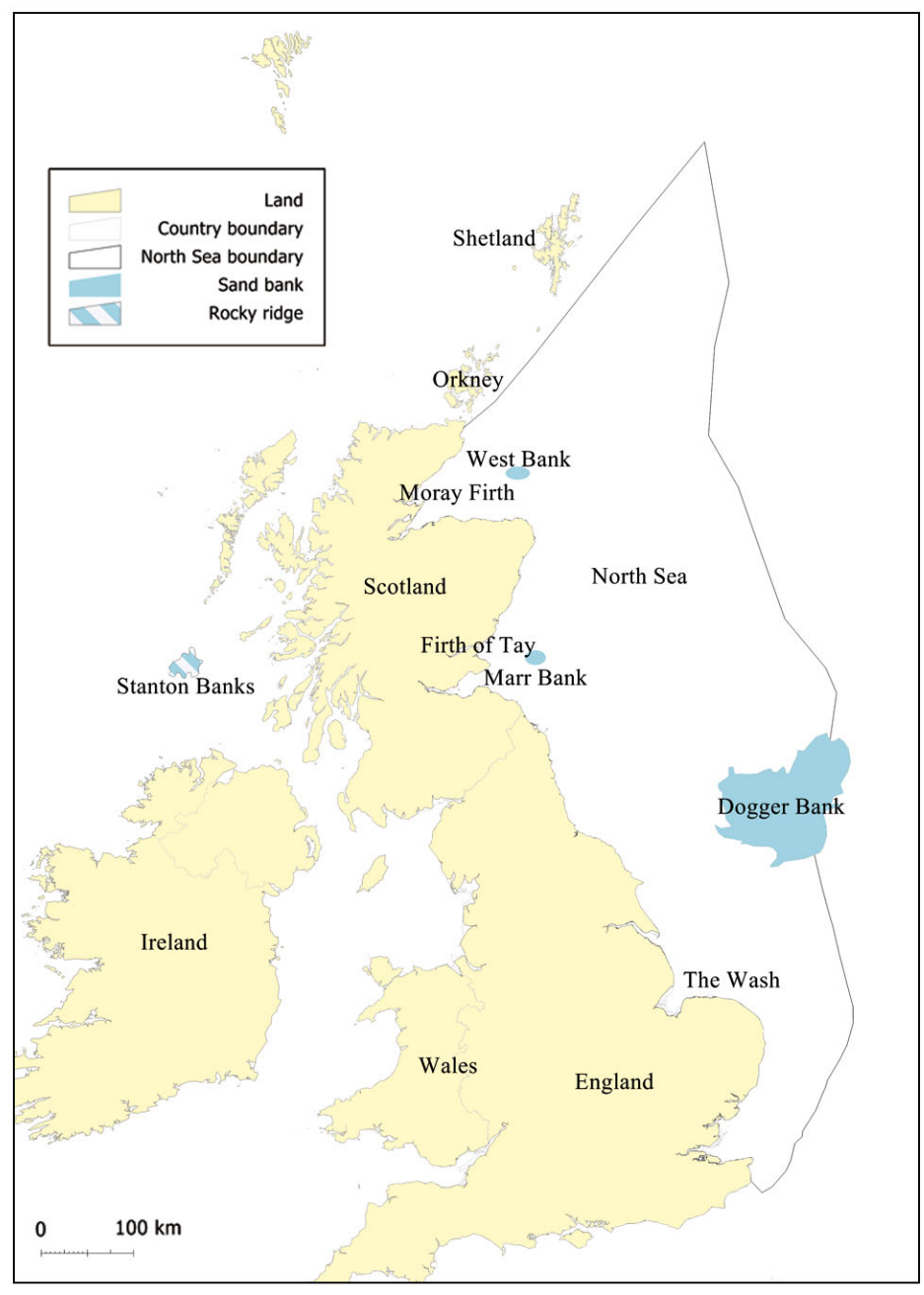

Fig. 7. Map of the British Isles showing key areas and locations referred to in the text

the telemetry data for each species at different times of the year. However, our examination of spatial partitioning between the 2 species is based on the assumption that patterns of usage remain constant. Grey seals show high pupping-site fidelity to aggregated colonies during the breeding season (Pomeroy et al. 2005). However, some animals travel to a site to pup but return after only a few weeks to non-breeding haul-out regions (Russell et al. 2013). This suggests that animals providing telemetry data during the breeding season may deviate from their nonbreeding behaviour for only a short time, having little impact on grey seal usage distribution. Male and female harbour seals have been shown to restrict their foraging range during the breeding season (Thompson et al. 1994, Van Parijs et al. 1997). However, lactation lasts around 24 d (Bowen et al. 1992), so this temporary behaviour is also unlikely to impact harbour seal usage distribution. To explore changes in the way that distributions of both species may vary annually and seasonally, more data collection is required. In the future, this may be possible through telemetry devices encompassing new technology such as extended tag lifetimes (years rather than months) and with the advent of more affordable devices so that tags could be deployed on many more animals.

\section{Informing conservation and management}

Quantifying species distributions and understanding the differences in the way apex predators utilise the marine environment has important implications for the impacts of anthropogenic activities and management action to mitigate such impacts. Grey and harbour seals are both listed in Annex II of the European Habitats Directive, which has led to the designation by the governments of the UK and the Republic of Ireland of a number of terrestrial MPAs, where grey or harbour seals are a qualifying feature (JNCC 2012, NPWS unpubl. data). No offshore MPAs have been proposed yet for these species, primarily because of the lack of robust science to inform this process. Here, we provide valuable new information, which together with other recent work (e.g. Russell et al. 2013), will allow governments to move towards selecting suitable sites to propose as marine MPAs for grey and harbour seals. We have shown that both species of seal spend the majority of their time at sea up to $50 \mathrm{~km}$ from the coast, but these areas are more important to harbour seals because they rarely move further from the coast; conservation and management action for harbour seals should therefore be focused in this zone. The exceptions are off The Wash and in the Moray Firth, where harbour seals spend more time farther offshore. Grey seal distribution is more extensive, and our results show that both offshore (presumed) foraging habitat and the transition corridors that link these foraging areas to haul-out sites are important to consider in the process of selecting marine MPAs. An important practical point arising from our results is that the uncertainty estimate for each grid square provides information about how representative the mean is of the underlying population. This provides information on the need for further 
data collection in areas of interest to conservation and management. Additionally, the results can be used directly in conservation planning tools such as Zonation software (http://cbig.it.helsinki.fi/software/ zonation/) that identifies areas important for habitat quality retention.

One issue of increasing conservation concern is the continuing rapid increase in marine renewable energy extraction in European waters (Edrén et al. 2010, Skeate et al. 2012, Thompson et al. 2013). Our results show that the impact of these developments on grey and harbour seals may vary because of differences in their spatial distributions. The effects of near-shore devices will potentially have a greater impact on harbour seals because a relatively greater proportion of the population will be exposed to the development. Conversely, a larger proportion of the grey seal population will be exposed to developments far offshore where corridors of usage form networks among offshore areas of high usage and haulout sites. Through comparing grey and harbour seal distributions, we found spatial partitioning over varying spatial scales showing that sympatric apex predators have dissimilarities in their spatial patterns in this case. Therefore, it should not be assumed that spatial prioritisation can be used effectively to conserve species at similar trophic levels or taxonomic groups, and there is a requirement for careful analysis of their distributions, as presented here, to properly inform spatial planning mechanisms.

\section{Broader applications}

Animal-borne sensors have developed and advanced over the past $25 \mathrm{yr}$, allowing many species to be tagged and producing large amounts of movement data (e.g. movebank.org). Density estimation is driven by movement data and does not rely on predictions of spatial usage, making it an ideal method where appropriate data are available. However, predictive modelling using underlying covariate data is suitable for areas where movement data are not available. The species density estimation combined with a simple habitat model framework presented here is applicable to a range of applications and datasets. The combined methodology presented here will be pertinent to species for which movement patterns of the whole population cannot be observed but population count data can be linked explicitly. In studies of marine central-place foragers, both sexes of seals and some seabirds can be counted reliably on land, tagged, and then tracked at sea, allowing insight into their spatial distribution. In the terrestrial environment, the methodology can be applied more widely as many terrestrial predators tend to be central-place foragers (e.g. wolves Canis lupus; Sand et al. 2005) and therefore relevant movement and population data are more readily available. Additionally, for environments where covariate data are spatially extensive and continuous, the accessibility modelling framework presented here could be extended to include readily available environmental covariates.

Acknowledgements. We thank the following people and institutions: Professor Paul Thompson, University of Aberdeen; Dr. Carol Sparling, SMRU Consulting; Ed Rowsell and Barry Collins, Chichester Harbour Conservancy; Jolyon Chesworth, Langstone Harbour Authority; Industry Nature Conservation Association; ZSL; Marine Current Turbines Ltd.; Northern Ireland Environment Agency; Department of Arts, Heritage, Gaeltacht and the Islands; Countryside Council for Wales; Welsh Assembly Government; Scottish Natural Heritage (SNH); National Environmental Research Council (NERC); Lisa Morgan, RSPB; Kate Lock and the Skomer Island wardens, Natural Resources Wales. E.L.J. and D.J.F.R. were funded under Scottish Government grant MMSS001/01. D.J.F.R. was funded by the UK Department of Energy and Climate Change (DECC) as part of their Offshore Energy Strategic Environmental Assessment programme. S.S. was partly funded by the EU MYFISH project.

\section{LITERATURE CITED}

Aarts G, Mackenzie ML, McConnell BJ, Fedak M, Matthiopoulos J (2008) Estimating space-use and habitat preference from wildlife telemetry data. Ecography 31:140-160

Argos (2011) Argos user's manual 2007-2011. Collecte Localisation Satellites (CLS). http://www.argos-system.org

Bailey H, Hammond PS, Thompson PM (2014) Modelling harbour seal habitat by combining data from multiple tracking systems. J Exp Mar Biol Ecol 450:30-39

Bexton S, Thompson D, Brownlow A, Barley J, Milne R, Bidewell C (2012) Unusual mortality of pinnipeds in the United Kingdom associated with helical (corkscrew) injuries of anthropogenic origin. Aquat Mamm 38: 229-240

Blundell GM, Maier Julie AK, Debevec EM (2001) Linear home ranges: effects of smoothing, sample size, and autocorrelation on kernel estimates. Ecol Monogr 71: 469-489

Bowen WD, Oftedal OT, Boness DJ (1992) Mass and energy transfer during lactation in a small phocid, the harbor seal (Phoca vitulina). Physiol Zool 65:844-866

Bowen WD, Ellis SL, Iverson SJ, Boness DJ (2003) Maternal and newborn life-history traits during periods of contrasting population trends: implications for explaining the decline of harbour seals (Phoca vitulina), on Sable Island. J Zool (Lond) 261:155-163

Boyd IL, Wanless S, Camphuysen CJ (eds) (2006) Top predators in marine ecosystems: their role in monitoring and management. Cambridge University Press, Cambridge

Brown SL, Bearhop S, Harrod C, McDonald RA (2012) A review of spatial and temporal variation in grey and com- 
mon seal diet in the United Kingdom and Ireland. J Mar Biol Assoc UK 92:1711-1722

> Chacón JE, Duong T (2010) Multivariate plug-in bandwidth selection with unconstrained pilot bandwidth matrices. Test 19:375-398

Coltman DW, Bowen WD, Wright JM (1998) Birth weight and neonatal survival of harbour seal pups are positively correlated with genetic variation measured by microsatellites. Proc R Soc Lond B 265:803-809

Cronin MA (2011) The conservation of seals in Irish waters: How research informs policy. Mar Policy 35:748-755

Duck CD, Morris CD (2013) Grey seal pup production in Britain in 2012: first complete survey using a digital system. Species Committee on Seals (SCOS) Briefing paper 13-01. www.smru.st-and.ac.uk/documents/1803.pdf

Duck CD, Morris CD, Thompson D (2013) The status of UK harbour seal populations in 2012. Species Committee on Seals (SCOS) Briefing paper 13-03. www.smru.st-and. ac.uk/documents/1803.pdf

> Dujon AM, Lindstrom RT, Hays GC (2014) The accuracy of Fastloc-GPS locations and implications for animal tracking. Methods Ecol Evol 5:1162-1169

Edrén SMC, Andersen SM, Teilmann J, Carstensen J, Harders PB, Dietz R, Miller LA (2010) The effect of a large Danish offshore wind farm on harbor and gray seal haulout behavior. Mar Mamm Sci 26:614-634

> Fieberg J (2007) Kernel density estimators of home range: smoothing and the autocorrelation red herring. Ecology 88:1059-1066

Gilbert JR, Waring GT, Wynne KM, Guldager N (2005) Changes in abundance of harbor seal in Maine, 19812001. Mar Mamm Sci 21:519-535

Guénette S, Heymans SJJ, Christensen V, Trites AW (2006) Ecosystem models show combined effects of fishing, predation, competition, and ocean productivity on Steller sea lions (Eumetopias jubatus) in Alaska. Can J Fish Aquat Sci 63:2495-2517

Hall AJ, Frame E (2010) Evidence of domoic acid exposure in harbour seals from Scotland: a potential factor in the decline in abundance? Harmful Algae 9:489-493

> Hall AJ, Jepson PD, Goodman SJ, Härkönen T (2006) Phocine distemper virus in the North and European Seasdata and models, nature and nurture. Biol Conserv 131: 221-229

> Harris CM, Travis JMJ, Harwood J (2008) Evaluating the influence of epidemiological parameters and host ecology on the spread of phocine distemper virus through populations of harbour seals. PLoS ONE 3:e2710

Hassani S, Dupuis L, Elder JF, Caillot E and others (2010) A note on harbour seal (Phoca vitulina) distribution and abundance in France and Belgium. NAMMCO Sci Publ 8:107-116

> Herreman JK, McIntosh AD, Dziuba RK, Blundell GM, BenDavid M, Greiner EC (2011) Parasites of harbor seals (Phoca vitulina) in Glacier Bay and Prince William Sound, Alaska. Mar Mamm Sci 27:247-253

Hooker SK, Cañadas A, Hyrenbach KD, Corrigan C, Polovina JJ, Reeves RR (2011) Making protected area networks effective for marine top predators. Endang Species Res 13:203-218

JNCC (Joint Nature Conservation Commttee) (2010) Council Directive 92/43/EEC on the Conservation of natural habitats and of wild fauna and flora. http://jncc.defra. gov.uk/page-1374 (accessed 19/07/2012)

JNCC (2012) 1365 Harbour seal (Phoca vitulina). http://
jncc.defra.gov.uk/ProtectedSites/SACselection/species. asp?FeatureIntCode=S1365 (accessed 19/07/2012)

Leeney RH, Broderick AC, Mills C, Sayer S, Witt MJ, Godley BJ (2010) Abundance, distribution and haul-out behaviour of grey seals (Halichoerus grypus) in Cornwall and the Isles of Scilly, UK. J Mar Biol Assoc UK 90:1033-1040

Lonergan M, Duck CD, Thompson D, Mackey BL, Cunningham L, Boyd IL (2007) Using sparse survey data to investigate the declining abundance of British harbour seals. J Zool (Lond) 271:261-269

Lonergan M, Duck C, Thompson D, Moss SE, McConnell BJ (2011) British grey seal (Halichoerus grypus) abundance in 2008: an assessment based on aerial counts and satellite telemetry. ICES J Mar Sci 68:2201-2209

Manifold Software Limited (2013) Manifold System Ultimate Edition 8.0.28.0. www.manifold.net

Matthiopoulos J, Aarts G (2010) The spatial analysis of marine mammal abundance. In: Boyd IL, Bowen WD, Iverson SJ (eds) Marine mammal ecology and conservation: a handbook of techniques. Oxford University Press, Oxford, p 68-97

> Matthiopoulos J, McConnell BJ, Duck C, Fedak M (2004) Using satellite telemetry and aerial counts to estimate space use by grey seals around the British Isles. J Appl Ecol 41:476-491

Matthiopoulos J, Harwood J, Thomas L (2005) Metapopulation consequences of site fidelity for colonially breeding mammals and birds. J Anim Ecol 74:716-727

McClintock BT, King R, Thomas L, Matthiopoulos J, Mcconnell BJ, Morales JM (2012) A general discretetime modeling framework for animal movement using multistate random walks. Ecol Monogr 82:335-349

McConnell BJ, Chambers C, Fedak MA (1992) Foraging ecology of southern elephant seals in relation to the bathymetry and productivity of the Southern Ocean. Antarct Sci 4:393-398

> McConnell BJ, Fedak MA, Lovell P, Hammond PS (1999) Movements and foraging areas of grey seals in the North Sea. J Appl Ecol 36:573-590

> McConnell BJ, Beaton R, Bryant E, Hunter C, Lovell P, Hall AJ (2004) Phoning home - a new GSM mobile phone telemetry system to collect mark-recapture data. Mar Mamm Sci 20:274-283

McCullagh P, Nelder JA (1989) Generalized linear models. Chapman \& Hall, London

> Merchant ND, Pirotta E, Barton TR, Thompson PM (2014) Monitoring ship noise to assess the impact of coastal developments on marine mammals. Mar Pollut Bull 78: 85-95

Ó Cadhla O, Keena T, Strong D, Duck C, Hiby L (2013) Monitoring of the breeding population of grey seals in Ireland, 2009-2012. Irish Wildl Manuals 74

Piatt JF, Sydeman WJ (2007) Introduction: a modern role for seabirds as indicators. Mar Ecol Prog Ser 352:199-204

> Pomeroy PP, Redman PR, Ruddell SJS, Duck CD, Twiss SD (2005) Breeding site choice fails to explain interannual associations of female grey seals. Behav Ecol Sociobiol 57:546-556

R Core Team (2014) R: a language and environment for statistical computing. R Foundation for Statistical Computing, Vienna. www.R-project.org/

Royer F, Lutcavage M (2008) Filtering and interpreting location errors in satellite telemetry of marine animals. J Exp Mar Biol Ecol 359:1-10

Russell DJF, McConnell BJ, Thompson D, Duck C, Morris C, 
Harwood J, Matthiopoulos J (2013) Uncovering the links between foraging and breeding regions in a highly mobile mammal. J Appl Ecol 50:499-509

Sand H, Zimmermann B, Wabakken P, Andren H, Pedersen HC (2005) Using GPS technology and GIS cluster analyses to estimate kill rates in wolf-ungulate ecosystems. Wildl Soc Bull 33:914-925

Sayer S, Hockley C, Witt MJ (2012) Monitoring grey seals (Halichoerus grypus) in the Isles of Scilly during the 2010 pupping season. Natural England Commissioned Report NECR103

Sharples RJ, Mackenzie ML, Hammond PS (2009) Estimating seasonal abundance of a central place forager using counts and telemetry data. Mar Ecol Prog Ser 378: 289-298

Sharples RJ, Moss SE, Patterson TA, Hammond PS (2012) Spatial variation in foraging behaviour of a marine top predator (Phoca vitulin) determined by a large-scale satellite tagging program. PLoS ONE 7:e37216

Silverman BW (1986) Density estimation for statistics and data analysis, 1st edn. Chapman \& Hall, London

Skeate ER, Perrow MR, Gilroy JJ (2012) Likely effects of construction of Scroby Sands offshore wind farm on a mixed population of harbour Phoca vitulina and grey Halichoerus grypus seals. Mar Pollut Bull 64:872-881

Svensson CJ (2012) Seal dynamics on the Swedish west coast: scenarios of competition as Baltic grey seal intrude on harbour seal territory. J Sea Res 71:9-13

Thomas L (2013) Estimating the size of the UK grey seal population between 1984 and 2012, using established and draft revised priors. Special Committee on Seals (SCOS). Briefing paper 13/02. www.smru.st-and.ac.uk/ documents/1803.pdf

Thompson PM, Miller D, Cooper R, Hammond PS (1994) Changes in the distribution and activity of female harbour seals during the breeding season: implications for their lactation strategy and mating patterns. J Anim Ecol 63:24-30

Thompson PM, McConnell BJ, Tollit DJ, Mackay A, Hunter C, Racey PA (1996) Comparitive distribution, movements and diet of harbour and grey seals from Moray Firth, NE

Editorial responsibility: Peter Corkeron, Woods Hole, Massachusetts, USA
Scotland. J Appl Ecol 33:1572-1584

Thompson D, Lonergan M, Duck C (2005) Population dynamics of harbour seals Phoca vitulina in England: monitoring growth and catastrophic declines. J Appl Ecol 42:638-648

Thompson PM, Brookes KL, Graham IM, Barton TR, Needham K, Bradbury G, Merchant ND (2013) Short-term disturbance by a commercial two-dimensional seismic survey does not lead to long-term displacement of harbour porpoises. Proc R Soc Lond B 280:20132001

Tollit DJ, Black AD, Thompson PM, Mackay A and others (1998) Variations in harbour seal Phoca vitulina diet and dive-depths in relation to foraging habitat. J Zool (Lond) 244:209-222

- Van Parijs SM, Thompson PM, Tollit DJ, Mackay A (1997) Distribution and activity of male harbour seals during the mating season. Anim Behav 54:35-43

Vincent C, McConnell BJ, Ridoux V, Fedak MA (2002) Assessment of SRDL location accuracy from satellite tags deployed on captive gray seals. Mar Mamm Sci 18: 156-166

> Vincent C, McConnell BJ, Delayat S, Elder JF, Gautier G, Ridoux V (2010) Winter habitat use of harbour seals (Phoca vitulina) fitted with Fastloc ${ }^{\mathrm{TM}}$ GPS/GSM tags in two tidal bays in France. NAMMCO Sci Publ 8:285-302

Waring GT, Gilbert JR, Belden D, Van Atten A, Digiovanni RA (2010) A review of the status of harbour seals (Phoca vitulina) in the Northeast United States of America. NAMMCO Sci Publ 8:191-212

Westcott SM, Stringell TB (2004) Grey seal distribution and abundance in North Wales, 2002-2003. CCW Marine Monitoring Report No. 13, Bangor

Williams R, Grand J, Hooker SK, Buckland ST and others (2014) Prioritizing global marine mammal habitats using density maps in place of range maps. Ecography 37 : 212-220

Wood SN (2006) Generalized additive models: an introduction with R. Chapman \& Hall, London

Wood SN (2011) Fast stable restricted maximum likelihood and marginal likelihood estimation of semiparametric generalized linear models. J R Stat Soc Ser B 73:3-36

Submitted: February 19, 2015; Accepted: May 22, 2015

Proofs received from author(s): August 3, 2015 